\title{
Little Known Aspects of Veneration of the Old Testament Sabbath in Medieval Ethiopia
}

\author{
Ekaterina V. Gusarova \\ Institute of Oriental Manuscripts of the Russian Academy of Sciences; \\ Manuscript Department of the National Library of Russia; National Research \\ University Higher School of Economics (St. Petersburg) \\ ekater-ina@mail.ru
}

\begin{abstract}
The Church of Ethiopia did observe both the Old Testament or the Jewish Sabbath and its Christian counterpart. This practice became one of the distinctive features of the Ethiopian Christianity. In various periods of its history the problem of veneration of the Jewish Sabbath provoked a lasting controversy among the country's clergy. It was under the reign of the King Zär'a Ya'əqob (1434-1468) that the observance of both Sabbaths became the officially accepted by the Ethiopian Church and the State. However, some evidences of this custom can be traced for many centuries before. Following the Confession offaith of the King Claudius (1540-1559), the priority was given to the celebration of Sunday. The author of the article was fortunate to discover several cases of the preferential veneration of Sunday during a military campaign of 1781 , described in the chronicle of the King Täklä Giyorgis I.
\end{abstract}

\section{Keywords}

Ethiopian Church - medieval Ethiopian Kingdom - Old Testament / Jewish Sabbath - veneration of Saturday and Sunday - King Zär’a Ya‘zqob - King Claudius - Ethiopian Royal chronicles - King Täklä Giyorgis I

* This article is an output of a research project implemented as part of the Basic Research Program at the National Research University Higher School of Economics (HSE). 
The influence of the Old Testament commandments on the Ethiopian Church rite and teachings has always been very significant. Although the Ethiopian Church until 1956 officially constituted an integral part of the Coptic Church, between both Churches there were considerable distinctions with regard to this matter. Contrary to the unambiguous position of the Alexandrian Patriarchate, which, in full agreement with the overwhelming majority of Christian confessions, replaced the Old Testament / Jewish Sabbath with Sunday, its flock in the Ethiopian metropolitan diocese continued to venerate both holydays. This religious rite still constitutes one of the most conspicuous and specific features of Christianity in the Horn of Africa.

The veneration of the Jewish Sabbath has still been kept among the Christians in modern Ethiopia. They get prepared for its celebration starting from Friday evening. They wash themselves, clean their dresses, cook for the next two days. That holiday is strictly observed. It is prohibited to work, to lit fire, go for long distances, to have sexual intercourses with women, ${ }^{1}$ etc. The periods of fasting are to be interrupted on Saturday. Every seventh Sabbath is celebrated with special liturgical songs. The first Patriarch of Ethiopia Basilius (Basəlyos), however, has pointed out that in the early 196oies the complete work prohibition was not practiced on in Addis Ababa on Saturdays. On these days the Addis Ababa market continued to be vibrant. ${ }^{2}$

The Sabbath in Ethiopian religious literature in the Ge'ez (Classical Ethiopic) language is commonly called sänbätä ayhud (the Jewish Sabbath), qädamit sänbät, sänbät qüdamit (the first Sabbath), or even qädam or nə’us sänbät (the minor Sabbath). For Sunday the Ge'ez language used expressions as sänbätä kərastiyan (the Christian Sabbath), sänbätä zhud (the Sabbath of the first day i.e. of the week), ahud sänbät or simply ahud (the first day) and also 'abiy sän$b \ddot{a t}$ (the great Sabbath). ${ }^{3}$

The observance of both Sabbaths on the same level was formally authorized in Ethiopia by the King Zär'a Ya'əqob (1434-1468) a skilled theologian. He became as such in the course of the ecclesiastic council, which took place in $145^{\circ}$ at his newly built church of Däbrä Məțmaq in the province of Shäwa. ${ }^{4}$ His Church regulations, including the practice to celebrate two Sabbaths, are

1 This prohibition is attested in the apocryphal Book of Jubilees (Jub. 50.12; cf. E. Hammerschmidt, Stellung und Bedeutung des Sabbats in Äthiopien (Studia Delitzschiana; Bd 7), Stuttgart, 1963, S. 27, Anm. 134).

2 Hammerschmidt, Stellung und Bedeutung, S. 2.

3 Cf. Hammerschmidt, Stellung und Bedeutung, S. 18. Strangely enough Ernst Hammerschmidt considered the genuine Ge'ez expressions nə'us sänbät and (')abiy sänbät as Amharic.

4 Tadesse Tamrat, Church and State in Ethiopia. 1270-1527. Oxford, 1972, pp. 228-231. 
recorded in great detail in his treatises, especially the 'Book of the Light' (Mäșhafä Barhan). Equally there was established the appropriate liturgical rite. As a theological background for the King Zär'a Ya'əqob served pseudoapostolic writings, such as Didascalia, Testamentum Domini and Statuta apostolorum. According to these texts, five day per week were reserved for work and only two for rest. Political reasons, which underplayed this decision by the King Zär'a Ya'əqob were to maintain a religious peace within his state as well as to an end to the long religious strife with the followers of St. Eustathius (马wosțatewos; 1273-1352) from the monastery of Däbrä Șärabi. This St. Eustathius was the founder of the so-called movement of "non-possessors", the movement, which later was instrumental to starting one of the most powerful monastic congregation of Ethiopia. The doctrine of St. Eustathius among others also included the equal veneration of both Saturday and Sunday. It has to be noted that before the reign of the King Zär'a Ya‘əqob the Eustathians were severely persecuted both by ecclesiastic and political authorities. ${ }^{5}$

It should be stressed here that according to the Vita of St. Eustathius he was a disciple of a certain Daniel from Däbrä Maryam, ${ }^{6}$ who in his turn went through his noviciate under the guidance of a certain Gbnä Sänbät, whose name (or rather nickname) significantly means the "stone of the Sabbath". It looks therefore like the observance and veneration of the Old Testament / Jewish Sabbath was "inherited" by St. Eustathius from his spiritual predecessors.

Such a suggestion finds its confirmation in the "History of Alexandrian patriarchs" by Sawirus ibn Mukaffa'. According to him, the Egyptian bishop Severus, who became the metropolitan of Ethiopia, asked the Coptic patriarch Cyril II (1077/1078-1092) to help to stop the observance of Judaic rites in Christian Ethiopia. ${ }^{7}$

In an inscription of the King Lalibäla (c.1190-1225) carved on the wooden altar (mänbärä tabot) in the monolith church Däbrä Sina (DSG 01) can be found the word sänbätiyan, which is the plural form of Sabbath, i.e. 'the two

5 A detailed account on the religious reform of Zär'a Ya'əqob and its sources is given in: Hammerschmidt, Stellung und Bedeutung, S. 19-40. About its part in the political history of Ethiopia see: Tadesse Tamrat, Church and State in Ethiopia. 1270-1527. Oxford, 1972, pp. 228-231.

6 See about him: G. Lusini, “Danə’el of Däbrä Maryam”, in: $E A E$, 2, 2005, pp. 85-86.

7 See about him: Sawirus Ibn al-Muqaffa', History of the Patriarchs of the Egyptian Church, Known as the History of the Holy Church, transl. by A. Khater, O.H.E. Burmester, Cairo, 1968-1970, pp. 347-351; D. Nosnitsin, "Sawiros", in: $E A E, 4,2005$, p. 565. It is to be noted that the veneration of the Judaic Sabbath stands alongside with other Veterotestamental commandments, such as the circumcision of boys and food taboos, commonly treated as Jewish. 
Sabbaths'8. This fact implies the veneration of both Saturday and Sunday in Ethiopian Church.

The decision by the King Zär'a Ya'əqob to observe the both holidays was fateful. It had its bearings on the liturgical rite of the Ethiopian Church. However, one is still not aware of the fact whether Saturday and Sunday had always the same status among Christians in the Horn of Africa.

In the mid-16th century AD the Portuguese arrival to Ethiopia provoked a new wave of discussion about the veneration of the Old Testament Sabbath. In response to accusations in observing Jewish rites the King Claudius (Gälawdewos; 1540-1559) wrote a treatise known as Confessio Claudii, subsequently first published by Hiob Ludolf. ${ }^{9}$ In this treatise the monarch emphasized that the Ethiopian Christians celebrated Saturday in another way that the 'crucifiers of Christ' and the veneration of the Sunday in commemoration of the Resurrection of our Lord is "much more" than the 'first Sabbath.' ${ }^{10}$ This statement by the King Claudius could still be considered as a part of polemics with Catholics, if it was not supported by evidences.

In some instances, however, it was not often the case. The late medieval Ethiopian annals say that in extraordinary circumstances, for instance in war, the Jewish Sabbath could not be observed. Also in the collection of chronicles, where the events of the period of political disintegration of Ethiopia are described (the late 18th - mid-19th century $\mathrm{AD}^{11}$ ) the veneration of Saturday is mentioned less frequently than the worship of Sunday. In some instances both Sabbaths were celebrated as rest-days. For example, this did take place during one of the military campaigns by Täklä Haymanot II (1769-1777) in the early 1770s. The chronicle narrates: "And they stayed at Ankäsha and took a rest [there] during 3 days in order to pay honour to [both] Sabbaths" (Orient. 821,

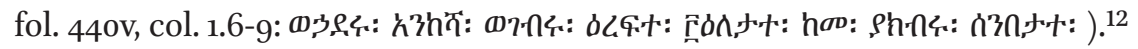

Cl. Bosc-Tiessé, "Catalogue des autels et meubles d'autel en bois (tābot et manbara tābot) des églises de Lālibalā. Jalons pour une histoire des objets et des motifs", Annales d'Éthiopie, 25 (2010), pp. 55-101, at pp. 74-76. The text is very short (Ibid., p. 76): "I inscribed

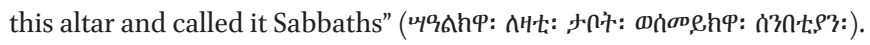

9 Its detailed analysis is given in: Hammerschmidt, Stellung und Bedeutung, S. 48-54.

10 Hammerschmidt, Stellung und Bedeutung, S. 51.

11 About this compilation, its only edition of poor quality and its manuscript copies see: E.V. Gusarova, "Joasaph II in an Unpublished List of the Metropolitans of the Ethiopian Church", Scr, 12 (2016), pp. 25-34, at pp. 27-28, n. 5 . Blundell, Cambridge, 1922, p. 11.29-30. In Eth. 143 (fol. 284v, col. 1.32-33) this passage is ren-

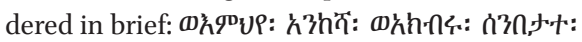


Another approach to the observance of the Old Testament Sabbath was demonstrated by the King Täklä Giyorgis I. He did reign for six times at the end of the 18th century AD. ${ }^{13}$ In his military expedition of the early 1781 in the north of his capital Gondär against a rebellious landlord called Gädlu he at least twice neglected the halt on the Old Testament Saturday:

- "And after that he stayed overnight at Bnqash and the next day, on Saturday, the 7 th of Tərr (January 13, 1781 - E.G.), the king rose up and went in the morning and camped at Məhurțäch ... and the day after, on the 8th of Țrrr, Sunday, he had a rest there" (Orient. 821, fol. 449v, col. 1.2-8, 9-12: $\omega_{\lambda} q^{\mathbf{p}}$

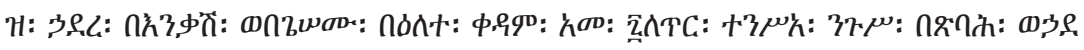

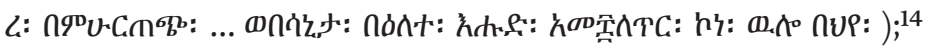

- "And the next day, on Saturday, the 14th of Țərr (January 20, 1781 - E.G.), the king rose up and went in the morning and camped at Adit, and the next day, on Sunday, the 15th of Tərr, he had a rest (Orient. 821, fol. 45or, col. 1.7-

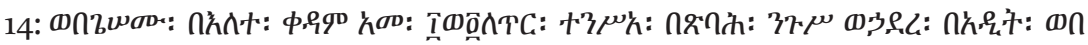

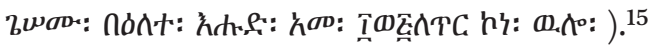

Otherwise at the same time the celebration of Sunday remained rather strict. The King Täklä Giyorgis I became very angry, when a battle with Gädlu took place on Sunday: "Everyone who fights today is not my subject, since Sunday is not a day of fight and war, but a day of rest and prayer" (Orient. 821, fol. 451v,

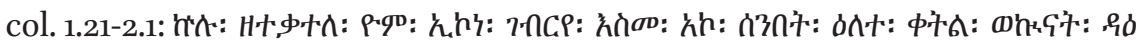

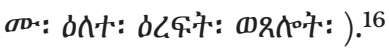

The priority given to Sunday over Saturday, albeit in exceptional situations, reflects the genuine Christian nature of the observance of the two Sabbaths in Ethiopia.

13 The precise dates of the periods of his reign are given in: Gusarova, "Joasaph II," p. 27.

14 Cf. The Royal Chronicle of Abyssinia, p. 23.19-20, 21. In Eth. 143 (fol. 29or, col. 2.10-11, 12-13)

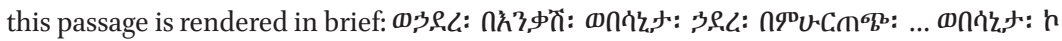
i: $a_{1}, n^{\circ}:$

15 Cf. The Royal Chronicle of Abyssinia, p. 26.11-12. In Eth. 143 (fol. 29ov, col. 1.18-20) this pas-

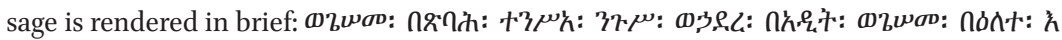

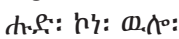

Cf. The Royal Chronicle of Abyssinia, p. 24.9-10. In Eth. 143 (fol. 291v, col. 1.2-4) this passage

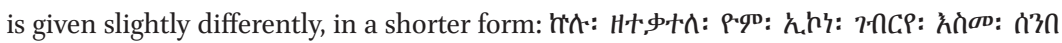

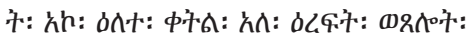

